\title{
Condition of large brood in Bonelli's Eagle Hieraaetus fasciatus
}

\author{
JAVIER BALBONTÍN* and MIGUEL FERRER \\ Department of Applied Biology, Estación Biológica de Doñana, Consejo Superior de Investigaciones \\ Científicas, Avda. de María Luisa s/n, Pabellón del Perú, Seville 41013, Spain
}

Capsule Young body condition is affected by the interaction of environment (rainfall) and brood size.

Aims To investigate factors affecting offspring condition using levels of urea in plasma.

Methods We used generalized linear mixed models (GLMMs) with the levels of urea in plasma as the dependent variable and laying date, brood size, sex and year as the explanatory ones.

Results Brood size had a significant effect on offspring condition only during a year of adverse weather (heavy rainfall). During this period, young from broods of two were in poor condition compared with single broods. Conversely, brood size had no effect in the other two years analysed. Neither sex nor laying date had a significant effect on young condition. Offspring condition was not related to first-year survival.

Conclusion There is a trade-off between reproduction (brood size) and offspring condition only in years of adverse environmental conditions.

Lack (1954) suggested that clutch size evolved to maximize the number of surviving young. This hypothesis predicts the existence of an intermediate optimal clutch size that depends on a trade-off between brood size and offspring survival. In studies that manipulate clutch or brood size the most productive clutch size is larger than the average clutch size of the population (Slagsvold 1982, Nur 1984). Experimental studies had shown that birds frequently tend to produce smaller clutches than they can actually rear (Klomp 1970). An extension of Lack's original theory states that clutch or brood size has evolved in order to maximize lifetime reproductive fitness (Cody 1966, Williams 1966, Charnov \& Krebs 1974, Tuomi 1990). This theory predicted a trade-off between fecundity and both parental and offspring survival.

Högstedt (1980) postulated that a bird population may comprise different individuals with different optimal clutch sizes. In particular, in territorial species, territory quality may explain an important part of the variation in clutch or brood size. Therefore, the fitness consequences of varying brood sizes can only be determined by experiment, where the brood size for a pair is manipulated away from their optimum or the environmental conditions are manipulated so that the optimum for any pair is changed.

*Correspondence author. Email: balbonja@ebd.csic.es
Bonelli's Eagle Hieraaetus fasciatus is a long-lived raptor. It is an endangered species (Rocamora 1994) with a maximum life span in captivity of 20 years (Newton 1979). It is characterized by a modal clutch size of two eggs (range 1-3, less than $1 \%$ of clutches with three eggs) and a mature reproduction age of about 3.5 years (Cramps \& Simmons 1980).

We investigate the relationship between offspring condition and brood size in 14 territories during a three-year period (1998-2000), with different environmental conditions (e.g. rainfall). We tested the effect of rainfall on the body condition of young of different brood sizes under natural conditions. Following Högstedt's hypothesis (1980), we predicted a cost in reproduction in terms of body condition only in years of adverse environmental conditions.

We used the level of urea and uric acid in the blood to evaluate nutritional condition (Ferrer 1994), as recommended by Alonso-Alvarez \& Ferrer (2001) and García-Rodriguez et al. (1987). The time a bird depletes its fat reserves and starts using muscle tissue as an energy source varies according to the individual's initial condition and the species' capacity for storing fat (Okumura \& Tasaki 1969, Ferrer et al. 1987, Balbontín \& Ferrer 2002). In raptors, protein catabolism activation occurs very quickly given the characteristic poor fat storage capacity of this group, a common feature in flying birds (Ferrer 1990). We 
controlled for laying date, because early breeding has been associated with an improvement in reproductive success in birds (Klomp 1970, Newton \& Maquiss 1984). Moreover, because Bonelli's Eagle showed reverse sexual size dimorphism and, hence, broods of two females would be the most expensive brood for the parents to rear, we also controlled for sex and the interaction between brood size and sex in the models.

\section{METHODS}

\section{Study area}

We studied a breeding population of Bonelli's Eagle in the province of Cádiz, (southern Spain, $5^{\circ} 32^{\prime} \mathrm{W}$, $\left.36^{\circ} 41^{\prime} \mathrm{N}\right)$. We monitored the breeding population of the Betics Mountains, the main mountain system of the region, comprising the Penibetic massif in the south, close to the Mediterranean sea, and the Subbetic one in the north. The altitude ranges from 80 to 3482 $\mathrm{m}$ asl and the climate is mediterranean and subarid (Rivas-Martinez 1986), with mean annual rainfall ranging from 200 to $1500 \mathrm{~mm}$. The landscape is characterized by a mosaic structure of forests (Quercus suber, Q. rotundifolia and Pinus spp.), matorral (Quercus coccifera, Thymus vulgaris and Rosmarinus officinalis), calcareous rocks, as well as pastures and fallow lands at lower altitudes.

\section{Data collection}

\section{Brood size and timing of reproduction}

We collected data on breeding biology and productivity of Bonelli's Eagle between 1998 and 2000, during which potential nesting cliffs were surveyed three times per year. The term 'nesting cliff' is used to denote the cliff where a pair attempted to breed, irrespective of whether they were successful or not. Between January and early February, we checked for territory occupancy (e.g. territorial displays, nest material transfer). A second check was made from late February to March to verify egg-laying, and the last visit occurred during April and May, to estimate the number of young fledged. The laying date was calculated by backdating from the age of nestlings on the basis of feather development, using personal observations at focal nests and information in Cramp \& Simmons (1980) and Torres et al. (1981). The sample size for brood size and laying date was from 41 territories checked during a three-year period (15 in 1998, 15 in 1999, and 11 in 2000).

\section{Offspring condition}

We took blood samples from 25 nestlings: 13 females and 12 males belonging to 14 different territories marked in three different years. Approximately $2 \mathrm{ml}$ of blood was taken from the brachial vein in the wing of nestlings 47 and 53 days old. Although plasma levels of urea and uric acid are both measures of body condition, to avoid redundancy, we only used plasma urea levels, since these two variables were correlated positively (Spearman's correlation, $r_{\mathrm{s}}=0.74, P<0.0001, n=25$ ). We collected all blood samples between 11:00 hours and 15:00 hours in lithium-heparin tubes. Blood was centrifuged and plasma separated $(10 \mathrm{~min}$ at 3000 rev./min) within $12 \mathrm{~h}$ after the sample was drawn, and both the cellular fraction and the plasma samples were immediately frozen $\left(-80^{\circ} \mathrm{C}\right)$. Analyses were carried out with a Hitachi 705 multichannel automatic analyser, with the reagents recommended by BoehringerMannheim (Darmstadt, Germany). Plasma was analysed (abbreviations and methods indicated in parentheses) for urea (UREA; urease method), uric acid (URAC; uricase method). In the range of values found for urea and uric acid plasma concentrations, the Hitachi 705 analyser showed a coefficient of variation of $6.25 \%$ and $2.39 \%$ for urea and uric acid respectively.

The cellular fraction of the blood sample was used to sex the young. For this analysis, primers 2945F, cfR and 3224R were used following Ellegren (1996). We used meteorological data (local precipitation) from the Spanish Meteorology Institute to analyse among-years differences in rainfall during the Bonelli's Eagle breeding season from January to June inclusive.

\section{Survival estimate}

At the time of marking, 28 young were equipped with $30-35$ g radio-transmitters representing $2-3 \%$ of their body weight at first flight. The radiotags were provided by Biotrack (Wareham, BH20 5AX, UK) and were fixed on the back of the eagle using a harness (Kenward 1987). We checked for radio signals from uniformly distributed observational points situated at great height to improve the distance at which the signal could be reached. This allowed us to receive a transmitter at an average distance of $40 \mathrm{~km}$ (range: 5-80 km). We had a total of 590 days of fieldwork, prospecting an area of about $16000 \mathrm{~km}^{2}$ every week from June 1998 to September 2000. Each young eagle was located at least three times every month from short distance triangulation $(2 \mathrm{~km})$ with $100 \mathrm{~m}$ tracking resolution. To calculate survival we used data from 1998 and 1999. The status of the young radiotagged in 2000 was not 
known after they were 115 days old and therefore they were excluded from this analysis. Another six young were also excluded because of either harness breaking or radio failure. This allowed us to collect data on young post-fledging survival during the first year of life (from age 50 days to age 420 days) for 16 eagles. Because young regularly come back to natal areas during dispersal (Balbontín \& Ferrer unpubl. data) and as no carcasses were found, we considered the status of an individual as dead only after loss of contact in the study area for at least two consecutive years.

\section{Statistical analysis}

We used generalized linear mixed models (GLMMs, Littell et al. 1996) using GLIMMIX macro procedure of the SAS package (SAS Institute 1990) to investigate factors affecting offspring condition measured through urea plasma levels. We used a normal distribution of errors and an identity link function. GLIMMIX automatically adjusts overdispersion by dividing the deviance by the extra-dispersion parameter. Hypotheses were tested using $F$-statistics for fixed effects and $z$-statistics for random effects (see Littell et al. 1996 for more details). The explanatory variables were laying date, brood size, sex, and year. Brood size, sex and year were considered fixed factors in the model. We collected our samples during a three-year period (1998-2000) that differed in environmental conditions (rainfall). Therefore, year was set as a fixed factor because our main interest was to analyse the effects that environmental conditions, might have on offspring condition. As several individuals (1-2 in the same year or 1-4 when taking all years into account) could be sampled in the same territory, we considered the territory as a random factor. Similarly, we used a second GLMM to study the relationship between survival and condition, using a binomial distribution of errors and logistic link function. In this analysis, survival was the dependent variable; brood size, sex and urea the explanatory ones. In this model we used the territory and year as random factors. To analyse seasonal and brood size trends among years non-parametric statistics were employed. All tests were two-tailed and statistical significance was set at $P<0.05$. Means are given with \pm 1 sd.

\section{RESULTS}

\section{Brood size}

Across all years, $68.3 \%$ of nests contained two young and $31.7 \%$ contained one young. We did not find any difference in brood size among years $\left(\chi_{2,41}^{2}=1.25, P=\right.$ $0.53)$. Laying date did not affect brood size $\left(F_{1,10}=\right.$ $0.00, P=0.96)$.

\section{Offspring condition}

Mean urea plasma was $14.55 \pm 4.83 \mathrm{mg} / 100 \mathrm{ml}$ (range: 5.50-26.00, $n=25$ ). The GLMM analysis showed a significant effect of the interaction between brood size and year $\left(F_{2,4}=7.70, P=0.04\right)$. Specifically, in 1998 young of double broods had a mean of $18.0 \pm 5.37 \mathrm{mg}$ urea/100 $\mathrm{ml}$ plasma and were therefore in poorer condition compared with other young (Fig. 1). Sex $\left(F_{1,4}=0.01, P=0.94\right)$ or laying date $\left(F_{1,4}=3.76, P=\right.$ 0.12 ) did not significantly affect offspring condition. The GLMM analysis also showed that year $\left(F_{2,4}=1.32\right.$, $P=0.36$ ) had no effect on offspring condition (Table 1). Covariance components associated with the random effect were significantly different from zero $($ covariance parameter estimate $=12.2219, z=2.09, P$ $<0.05)$. This showed that the variation in urea levels within territories was smaller than among territories, but it does not influence all inferences made about the fixed factors.

\section{Offspring condition and survival}

During a one-year period, five out of 16 young (31.25\%) were dead. The GLMM analysis did not show any significant effect of either brood size $\left(F_{1,2}=0.00, P=0.98\right)$, sex $\left(F_{1,2}=1.48, P=0.34\right)$ or urea plasma concentration $\left(F_{1,2}=1.38, P=0.36\right)$ on young survival

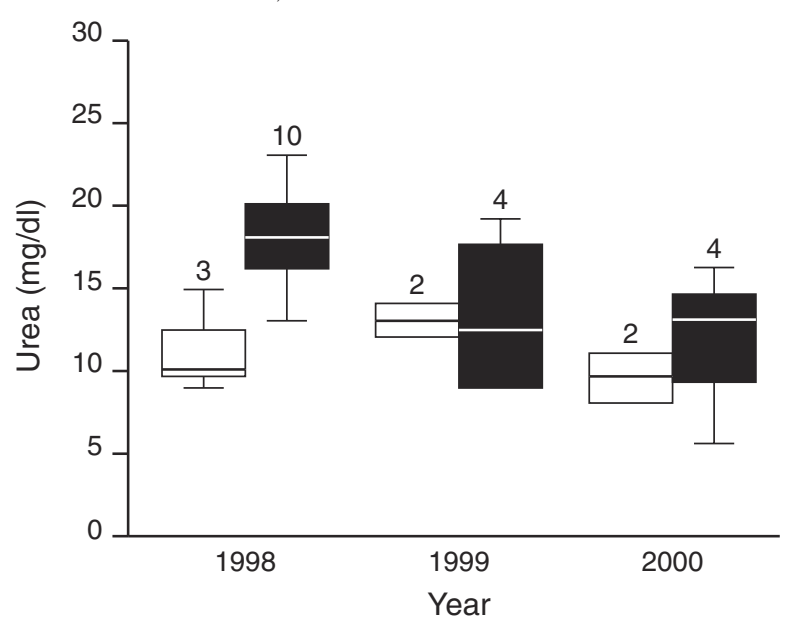

Figure 1. Effect of brood size on offspring condition (plasma urea levels) in Bonelli's Eagle during a three-year period with different environmental conditions: favourable (1999 and 2000) and unfavourable, due to high rainfall (1998). Brood size: $\mathbf{\square}, 1$ offspring; $\boldsymbol{\square}, 2$ offspring. 
Table 1. GLMMS for explaining the distribution of urea plasma levels in offspring of Bonelli's Eagle.

\begin{tabular}{lrc}
\hline Effect & Estimate & se \\
\hline Intercept & 7.0917 & 2.3920 \\
Laying date & 0.4347 & 0.2243 \\
Year 1998 & 7.3313 & 1.4956 \\
Year 1999 & 3.4064 & 1.1901 \\
Year 2000 & 0.0000 & - \\
Sex & -1.5009 & 0.8502 \\
Brood size & -0.4083 & 3.1321 \\
Brood size $\times$ Sex & 2.7594 & 2.9436 \\
Brood size $\times$ year 1998 & -8.5025 & 3.1021 \\
Brood size $\times$ year 1999 & -1.5546 & 4.0101 \\
Brood size $\times$ year 2000 & 0.0000 & - \\
\hline
\end{tabular}

Table 2. GLMMs for explaining first-year offspring survival in Bonelli's Eagle.

\begin{tabular}{lrc}
\hline Effect & Estimate & se \\
\hline Intercept & 4.8242 & 4.1922 \\
Brood size & 17.7819 & 771.04 \\
Sex & 2.5263 & 2.0798 \\
Urea plasma levels & 0.2451 & 0.2087 \\
\hline
\end{tabular}

(Table 2). Covariance components associated with random effects were very close to zero in this model.

\section{DISCUSSION}

Brood size was inversely related to offspring condition only during a year of adverse environmental circumstances. In our study area, 1998 was a year with heavy precipitation during the eagles' breeding season. In 1998 mean rainfall was significantly higher $(26.8 \pm$ $44.6 \mathrm{~mm}$ ) than during the breeding season of 1999 and $2000(16.7 \pm 25.5 \mathrm{~mm})(z=1.425, P=0.05)$. Therefore, differences in environmental factors between years influence the effect of brood size on offspring condition. Rainfall or severe winter weather can affect breeding performance in birds, including raptors (Kostrzewa \& Kostrzewa 1990, Penteriani 1997). In particular, rain might affect the time an eagle has available for foraging and also depress foraging performance (Hirons 1982, Village 1986). Frequent rain might interfere in prey detection and might increase the energy cost needed for gliding flights. Pairs of eagles rearing two young pay a cost in terms of the body condition of their progeny when rain is frequent, because it does not allow parents to obtain all resources needed for rearing good quality young.
It has been frequently demonstrated that females reproducing earlier in the season produced larger broods or litters with offspring in better physical condition (Klomp 1970, Newton \& Maquiss 1984, Ferrer 1994). For example, early Spanish Imperial Eagle Aquila adalberti nestlings were better nourished than later ones (Ferrer 1994). In this study, we did not find a significant seasonal change either in brood size or offspring condition. Neither did we find significant differences in offspring condition between sex or in the interaction between brood size and sex.

Offspring condition has been related to survival in birds (Williams et al. 1993, Sedinger et al. 1995). However, we did not find a relationship between condition and first-year survival of young. Although we did not find a relationship between these parameters, offspring condition could be related to other life history traits not investigated in this study, such as year at first breeding. Some studies have shown an inverse correlation between brood size and post-fledging survival (Ross \& McLaren 1981, Nur 1984). We found that first-year survival was not related to brood size.

According to clutch size optimization models (Lack 1954), optimal clutch size maximizes the number of surviving young. Contrary to Lack's prediction, and as postulated by Högstedt (1980), a bird population may comprise different individuals with different optimal clutch sizes. In particular, in territorial species, territory quality may explain an important part of the variation in clutch or brood size. Good-quality territories would have an optimal brood size that is larger than the one found in poor-quality territories. Fledging condition and survival might also differ among territories. Furthermore, yearly differences in food availability would prevent individuals from achieving their maximum output. Our results suggest the existence of a trade-off between reproduction (brood size) and offspring condition at least during years of adverse environmental circumstances in this longlived raptor, consistent with the idea that there is an individual optimum brood size for a particular set of environmental conditions. Although we agree with Lack's idea that some of the requisite information can be obtained from manipulation studies, following Endler (1986) much can be gained by studies of wild populations on which such an approach could not be used, such as endangered large birds of prey.

\section{ACKNOWLEDGEMENTS}

We thank E. Minguez, J.R. Benitez, V. Siebering, G. Moreno, C. Aguilar, J.A. Gil and E. Sáez for their help with the field- 
work. We also thank E. Calvo for climbing the nest-cliffs. C.F. Vega and C. Alonso-Alvarez helped with the blood analysis. F. Recio and the laboratory staff of Valme Hospital kindly allowed us to use the laboratory equipment. A draft was revised and improved by F. Sergio, V. Penteriani and W. Cresswell. This study was supported by the Andalusia Goverment (Junta de Andalucia, Consejeria de Medio Ambiente).

\section{REFERENCES}

Alonso-Alvarez, C. \& Ferrer, M. 2001. A biochemical study about fasting, subfeeding and recovery processes in yellow-legged gulls. Physiol. Biochem. Zool. 74: 703-713.

Balbontín, J. \& Ferrer, M. 2002. Plasma chemistry reference valves in free-living Bonelli's eagle Hieraaetus fasciatus nestlings. J. Raptor Res. 36: 231-235.

Charnov, E.L. \& Krebs, J.R. 1974. On clutch size and fitness. Ibis 116: 217-219.

Cody, M.L. 1966. A general theory of clutch size. Evolution 20: 174-184.

Cramp, S. \& Simmons, K.E.L. 1980. Handbook of the Birds of Europe, the Middle East and North Africa, Vol. 2. Oxford University Press, Oxford.

Ellegren, H. 1996. First gene on the avian W Chromosome (CHD) provides a tag for universal sexing of non-ratite birds. Proc. R. Soc. Lond. B. 263: 1635-1641.

Endler, J.A. 1986. Natural Selection in the Wild. Princeton University Press, Princeton, NJ.

Ferrer, M. 1990. Hematological studies in birds. Condor 92: 1085-1086.

Ferrer, M. 1994. Nutritional condition of Spanish Imperial Eagle nestling Aquila adalberti. Bird Study 41: 120-123.

Ferrer, M., Garcia-Rodriguez, T., Carrillo, J.C. \& Castroviejo, J. 1987. Hematocrit and blood chemistry values in captive raptors. Comp. Biochem. Physiol. 87A: 1123-1127.

García-Rodriguez, T., Ferrer, M. , Carrillo, J.C. \& Castroviejo, J. 1987. Metabolic responses of Buteo buteo to long-term fasting and refeeding. Comp. Biochem. Physiol. 87A: 381-386.

Hirons, G.J.M. 1982. The effects of fluctuations in rodent numbers on breeding success of tawny owl Strix aluco. Mammal Rev. 14: 155-157.

Högstedt, G. 1980. Evolution of clutch-size in birds: adaptive variations in relation to territory quality. Science 210: 1148-1150.

Kenward, R.E. 1987. Wildlife Radio Tagging. Academic Press, London.

Klomp, H. 1970. The determination of clutch size in birds. A review. Ardea 58: 1-124.
Kostrzewa, R. \& Kostrzewa, A. 1990. The relationship of spring and summer weather with density and breeding performance of the buzzard Buteo buteo, goshawk Accipeter gentilis and Kestrel Falco tinninculus. Ibis 132: 550-559.

Lack, D. 1954. The Natural Regulation of Animal Numbers. Oxford University Press, Oxford.

Littell, R.C., Milliken, G.A., Stroup, W.W. \& Wolfinger, R.D. 1996. SAS System for Mixed Models. SAS Institute Inc., Cary, NC.

Newton, I. 1979. Population Ecology of Raptors. Buteo Books, Vermillion, South Dakota.

Newton, I. \& Maquiss, M. 1984. Seasonal trend in the breeding performance of Sparrowhawk. J. Anim. Ecol. 53: 809-829.

Nür, N. 1984. The consequences of brood size for breeding blue tits. I. Adult survival, weight change and the cost of reproduction. J. Anim. Ecol. 53: 479-496.

Okumura, J. \& Tasaki, I. 1969. Effect of fasting, refeeding and dietary protein level on uric acid and ammonia content of blood, liver and kidney in chickens. J. Nutr. 97: 316-320.

Penteriani, V. 1997. Long-term study of a goshawk breeding population on a Mediterranean mountain (Abruzzi Apennines, central Italy): density, breeding performance and diet. J. Raptor Res. 31: 308-312.

Rivas-Martínez, S. 1986. Memoria del mapa de las series de vegetación de España. ICONA, Madrid.

Rocamora, G. 1994. Bonelli's Eagle Hieraaetus fasciatus. In Tucker, G. M. \& Heath, F. M. (eds) Birds in Europe. Their Conservation Status. Birdlife International, Cambridge.

Ross, H.A. \& McLaren, I.A. 1981. Lack of differential survival among young lpswich sparrows. Auk 98: 495-502.

SAS Institute 1990. SAS/STAT User's Guide. Version 6. SAS Institute Inc., Cary, NC.

Sedinger, J.S., Flint, P.L. \& Lindberg, M.S. 1995. Environmental influence of life-history traits: growth, survival and fecundity in Black Brant (Branta bernicla). Ecology 76: 2404-2414.

Slagsvold, T. 1982. Clutch size, nest size, and hatching asynchrony in birds: experiments with the fieldfare (Turdus pilaris). Ecology 63: 1389-1399.

Torres, J.A, Jordano, P. \& León, A. 1981. Aves de Presas Diurnas de la Provincia de Córdoba. Publicaciones del Monte de Piedad y Cajas de Ahorros de Córdoba, Madrid.

Tuomi, J. 1990. On clutch size and parental survival. Oikos 58: 387-389.

Village, A. 1986. Breeding performance of kestrels at Eskdalemuir, south Scotland. J. Zool. Lond. A 208: 367-378.

Williams, G.C. 1966. Natural selection, the cost of reproduction and a refinement of Lack's principle. Am. Nat. 100: 687-690.

Williams, T.D., Cooch, E.G., Jeffereis, R.L. \& Cooke, F. 1993. Environmental degradation, food limitation and reproductive output; juvenile survival in Lesser Snow Geese. J. Anim. Ecol. 62: 766-777. 